3. Bleser WK, Miller-Day M, Naughton D, Bricker PL, Cronholm PF, Gabbay RA. Strategies for achieving whole-practice engagement and buy-in to the patient-centered medical home. Ann Fam Med. 2014;12(1):37-45.

4. Peterson LE, Blackburn BE, Puffer JC, Phillips RL Jr. Family physicians' quality interventions and performance improvement through the ABFM diabetes Performance in Practice Module. Ann Fam Med. 2014;12(1):17-20.

5. Rat C, Quereux G, Riviere C, et al. Targeted melanoma prevention intervention: a cluster randomized controlled trial. Ann Fam Med. 2014;12(1):21-28.

6. Ferrer RL, Cruz I, Burge S, Bayles B, Castilla MI. Measuring capability for healthy diet and physical activity. Ann Fam Med. 2014;12(1): 46-56.

7. Ambresin G, Chondros P, Dowrick C, Herrman H, Gunn JM. Selfrated health and long-term prognosis of depression. Ann Fam Med. 2014;12(1):57-65.

8. Ebell MH, Lundgren J, Youngpaoroj S. How long does a cough last? Comparing patients' expectations with data from a systematic review of the literature. Ann Fam Med. 2013;11(1):5-13.

9. Mustafa M, Wood F, Butler CC, Elwyn G. Managing expectations of antibiotics for upper respiratory tract infections: a qualitative study. Ann Fam Med. 2014;12(1):29-36.
10. Sturmberg JP, Martin C, Katerndahl DA. Systems and complexity thinking in the general practice literature: an integrative, historical narrative review. Ann Fam Med. 2014;12(1):66-74.

11. Annals Journal Club: Managing expectations for antibiotics when seeing patients with upper respiratory tract infections. Ann Fam Med. 2014;12(1)iii.

12. Generation III-Keystone III Working Group. A view from Cheyenne Mountain: Generation III's perspective of Keystone III. Ann Fam Med. 2014;12(1):75-78.

13. Martin JC, Avant RF, Bowman MA, et al; Future of Family Medicine Project Leadership Committee. The future of family medicine: a collaborative project of the family medicine community. Ann Fam Med. 2004;2(Suppl 1):S3-32.

14. Steiner E; for the Generation III-Keystone III Working Group. The changing world of family medicine: the new view from Cheyenne Mountain. Ann Fam Med. 2014;12(1):3-5.

15. Stange KS, Frey JJ III. Unresolved intergenerational issues. Ann Fam Med. 2014;12(1):5-6.

16. Rowland $\mathrm{K}$. The voice of the new generation of family physicians. Ann Fam Med. 2014;12(1):6-7.

\title{
EDITORIAL
}

\section{The Changing World of Family Medicine: The New View From Cheyenne Mountain}

\author{
Elizabeth Steiner, MDi for the Generation III-Keystone III Working Group \\ Ann Fam Med 2014;3-5. doi: 10.1370/afm.1621
}

E lectronic health records. Smart phones. Near-universal broad-band Internet access. Asynchronous communication. Electronic visits. Telemedicine. Patient-centered primary care homes (medical homes). Team-based care. A wide range of practice models. Hospitalists. Value-based purchasing. Accountable care. In the 13 years since the Keystone III conference that set the stage for the Future of Family Medicine (1.0) initiative, which attempted to renew and transform the discipline of family medicine, these innovations have all become commonplace, resulting in one of the most substantial transformations of primary care practice in the past century. The 10 members of the Generation III (youngest generation) group at the conference have been closely involved with many of these changes through practice, policy, research, and medical education $_{i}$ in many ways these changes represent a microcosm of the diversity among family physicians today.

As our original article makes clear, the definition of the "ideal" family physician was a recurrent theme during the Keystone conference. Those of us in Generation III, some late baby boomers and some early Gen Xers (those born 1964-1985), undoubtedly had expectations of work-life balance, the scope of our practices, and how we might structure our practices and careers that were different from those held by Generations I and II. Over the intervening years, it has become evident that one might best describe the ideal family physician as a pluripotent stem cell; our generalist inclination, diverse training, and range of meta-skills (listening, systems thinking, team-building, advocacy, etc) allow family physicians to pursue a wide range of careers both in and out of medicine, and even change

\section{CORRESPONDING AUTHOR}

Elizabeth Steiner, MD

Oregon Health \& Science University

3181 SW Sam Jackson Park Rd, Mail Code FM

Portland OR 97239

steinere@OHSU.edu 
careers within family medicine. Nationally, family physicians lead government programs, serve as medical directors for corporations and insurance companies, invent new technologies, develop and franchise new models of practice, and enter additional professions, such as politics, information technology (IT), law, and business. Even among the 10 of us, we have 3 department chairs, an associate dean, a mayor, a state senator, a medical director of Planned Parenthood, a state Medicaid director, a research director for a nonprofit IT collaborative, and a chief executive officer of a direct primary care organization. Each of us has chosen to interpret our mission as a family physician differently and believes that each is serving as a family physician every day, regardless of whether we see a patient that day in a traditional family medicine clinic.

The historical article presented in this issue, written by our group immediately after the Keystone III conference, reflects well the overall tenor of the conversation around family medicine at the beginning of the century. We were, in many ways, playing defense, frustrated by the increasing industrialization of medicine, with terms such as relative value units and productivity permeating our daily practice. This industrialization only accelerated in the decade after Keystone III, becoming almost an arms race between the various segments of the health care system; clinicians were trying to maximize revenue by any means possible, and payers were instituting complex mechanisms to control costs. The economic boom that allowed medical costs to balloon without consequence, pushing high-tech rather than high-touch as the best form of health care, even as health outcomes worsened, further exacerbated industrialization. Family physicians were dragged further and further away from our core: whole-person, whole-family, and whole-community-centered care. We responded and continue to respond through various strategies to preserve that core.

In response to the unsustainable trajectory of health care costs seen by politicians, employers, insurers, and providers of health care of all types, the family of family medicine ultimately has chosen a more proactive course. We have engaged increasingly in advocacy, and many family physicians have taken on new roles in leadership, both in medicine and beyond. We have reframed the conversation and educated the public and decision makers about the value of prevention rather than cure, as well as the necessity of empowering and partnering with patients to improve their health care experience and health outcomes. In many ways, family physicians have had a substantial influence on the Affordable Care Act, which will have lasting implications on the future of health care in the United States.
Furthermore, family medicine has been a leader in developing the evidence for and implementation of practice redesign and payment reform. Family medicine appears to be adapting more rapidly than most specialties to practice-based research and the technologic changes in care delivery. Many family physicians understand that direct, one-on-one, face-to-face contact may not always represent the best, most patientcentered care. For example, many use asynchronous communication by means of the electronic health record to help patients with diabetes adjust their insulin dosing, rather than rely on frequent office visits. Paradoxically, many in our generation have found that the ability to be always on call using modern technology has decreased our anxiety about work-life balance (eg, we can go home directly after office hours are done, have dinner with our families, and finish charting later from home) and allowed us to focus on one of the aspects of family medicine-true engagement with our patients-that drew us to the specialty in the first place. Those of us in regular contact with students and residents find the same to be true of later Generation III and early Generation IV members (roughly speaking, those entering practice after 2004, when electronic health records became more common place).

Our work with learners has also changed dramatically as a result of technology and practice models. We have learned, and now must teach, electronic health record data extraction and analysis, asynchronous communication with patients, population health management, and systems thinking. The national move toward patient-centered primary care homes has required us to move toward a more interprofessional model of training, which will only increase in years to come. Our tradition of understanding the importance of aligning primary care, mental health, and public health enables us to teach learners about how improvements in our patients' mental well-being and social determinants of health might be more important to their health than the care provided in the academic health center hospital.

Ultimately, our group of 10 Generation III members believes that family medicine represents the professional expression of evolution. Particularly during the past decade, our specialty has demonstrated the ability to not only adapt to a rapidly changing health care ecosystem, but to thrive in it, and to shape it to advance what we've always known-true primary care can and should be delivered in a wide range of settings and modalities, and when practiced in ways that promote patient-centeredness and physician wellbeing, we deliver health care that improves health, lowers cost, and enhances the patient experience. 
To read or post commentaries in response to this article, see it online at www.annfammed.org/content/12/1/3.

Key words: history of medicine; family practice; family medicine; delivery of health care
Generation III-Keystone III Working Group Members: Erika Bliss, MD; Kara Cadwallader, MD; Terrence E. Steyer, MD; Deborah S. Clements, MD; Jennifer E. DeVoe, MD; Kenneth Fink, MD; Marina Khubesrian, MD; Paul Lyons, MD; Elizabeth Steiner, MD; and David Weismiller, MD.

Submitted October 15, 2013; accepted December 19, 2013.

\title{
EDITORIAL
}

\section{Unresolved Intergenerational Issues}

\author{
Kurt C. Stange, MD, PbD, Jobn J. Frey III, MD, Editors \\ Ann Fam Med 2014;5-6. doi: 10.1370/afm.1613.
}

T The Keystone III Conference was held October 4-8,2000, as a structured conversation about the current state and future of family medicine. ${ }^{1,2}$ Inspired by prior conversations organized by family medicine pioneer G. Gayle Stephens, MD, in 1984 and $1988,{ }^{3}$ Keystone III stimulated the Future of Family Medicine Project, which aimed to "transform and renew the discipline of family medicine to meet the needs of patients in a changing health care environment." This project, in turn, influenced the genesis of the patient-centered medical home ${ }^{5}$ and affected the course of US family medicine organizations' efforts over the past decade. A widespread feeling still exists, however, that the work of renewal and transformation is not yet finished-that some precious ideals must be retained or reinvented, even as the Affordable Care Act moves health care change forward at an accelerating pace, and diverse new approaches to health care emerge. In fact, a Future of Family Medicine 2.0 already is underway. ${ }^{6}$

Perhaps the most vital aspect of the organization of the Keystone III conference was its purposeful multigenerational assembly. The conference was ordered around 8 papers presented by pairs of authors from different generations. ${ }^{2}$ The pioneers who largely came out of general practice to start the academic discipline of family medicine were reverently referred to as Generation I. The settlers, who largely trained in the residencies that Generation I had set up, were now in practice, leadership, or academic positions. They were called Generation II. Generation III were the young family physicians who either were in training or newly in practice or teaching at the turn of the 21 st century. The great value of the intergenerational organization of the conference will be apparent to anyone with experience with multigenerational families, where the wisdom and mischief of experience reaches a flash point with the mischief and insight of youth, and the connections that can occur between grandparents and youngsters. The middle group is often tasked with balancing and operationalizing the competing threads of dialogue.

For us, the major unresolved business of Keystone III was an intergenerational conversation that remained unmined for its gold.

A crystallizing event occurred as a senior leader gave his usual brilliant summary of one of the papers and discussion, hoping to lead participants into a break on a thoughtful note. As part of his summary, he said: "We might find, that as we become less willing to be available to our patients $24 / 7$, our moral authority is diminished." As everyone started to get up to go, a Generation II participant from the back row jumped up, grabbed a microphone, and shouted, "How can you say that! How can you say that to be a good family physician I have to be an absentee father, and an unavailable spouse, and not have interests outside of medicine?" As people continued on to their conference break, and in small conversations at mealtimes, the need to reconcile these two perspectives became a focal point. But those conversations were never publicly vetted and certainly were never resolved.

Into this unsettled space comes a paper that the Generation III participants wrote shortly after the Keystone III conference, but never published, and which will, we hope, restart that essential, lingering conversation in preparation for the next period of examination and renewal. In this issue, we publish it with minor editorial changes, ${ }^{7}$ and publish the reflections of its authors who are now in mid career almost 14 years 